\title{
PRODUKSI DAN NUTRISI HIJAUAN OKRA SEBAGAI PAKAN PADA SISTEM INTEGRASI TANAMAN-TERNAK
}

\author{
Dwi Retno Lukiwati \\ Fakultas Peternakan dan Pertanian,Universitas Diponegoro. Semarang \\ email: drlukiwati_07@yahoo.com
}

\begin{abstract}
ABSTRAK
Ciri khas sistem integrasi tanaman-ternak adalah hasil utama tanaman pertanian untuk pangan atau sayuran, jerami atau hijauannya untuk pakan ternak ruminansia sedangkan pupuk kandang (pukan) digunakan sebagai pupuk organik. Fosfor (P) termasuk unsur hara utama dan merupakan salah satu faktor pembatas produksi tanaman. Batuan fosfat (BP) sebagai salah satu pupuk P organik yang dapat ditingkatkan kelarutannya apabila dicampurkan bersamaan dengan proses dekomposisi pupuk organik. Tujuan penelitian ini untuk menguji pengaruh beberapa macam pupuk organik terhadap produksi dan kadar nutrisi daun okra (Abelmoschus esculentus L) sebagai hijauan pakan. Penelitian telah dilaksanakan di kebun percobaan dengan rancangan acak kelompok, 9 perlakuan dan 3 ulangan. Perlakuan yang diberikan adalah T1 (BP), T2 (kompos azolla), T3 (pukan sapi), T4 (pukan kambing), T5 (pukan ayam), T6 (kompos azolla+BP), T7 (pukan sapi+BP), T8 (pukan kambing+BP), T9 (pukan ayam+BP). Pemangkasan hijauan dilakukan pada umur 80 hari setelah tanam, kemudian ditimbang untuk mengetahui produksi segar hijauan dan dianalisis kadar nitrogen serta fosfor. Hasil penelitian menunjukkan bahwa perlakuan pemupukan berpengaruh nyata terhadap produksi segar hijauan, kadar N dan P. Hasil uji DMRT menunjukkan bahwa produksi hijauan segar, kadar $\mathrm{N}$ dan $\mathrm{P}$ nyata lebih tinggi jika dipupuk pukan kambing+BP (T8) dan pukan ayam+BP (T9) dibanding perlakuan lainnya.
\end{abstract}

Kata kunci: Abelmoschus esculentus L, batuan fosfat, pupuk kandang, nutrisi, produksi

\begin{abstract}
The characteristics of crop-livestock systems is crop yield for food or vegetable, and stover or leaf for ruminant feed, being the manure used as organic fertilizer. Phosphorus (P) is the major plant nutrient and considered one of the primary factors limiting crop yields. Rock phosphate (RP) is one of some organic P fertilizer which could increased its solubility if mixed at the initial phase of manure decomposition process. The objective of the research was to investigate the influence of some kind of organic fertilizer on production and nutrient concentration of okra (Abelmoschus esculentus $\mathrm{L}$ ) leaf as forage. A field experiment of randomized block design with 9 treatments and three replicates was done, and the treatments were T1 (RP), T2 (azolla compost), $\mathrm{T}_{3}$ (cow manure), $\mathrm{T} 4$ (goat manure), $\mathrm{T} 5$ (poultry manure), $\mathrm{T} 6$ (azolla+RP), $\mathrm{T} 7$ (cow manure+RP), T8 (goat manure+RP), T9 (poultry manure+RP). Okra leaf defoliated at 80 days after planting, and continued measured for fresh leaf production, nitrogen and phosphorus concentration. The results showed that the treatment significantly affected to the fresh leaf production, concentration of nitrogen and phosphorus. The result of DMRT showed that fresh leaf production, concentration of $\mathrm{N}$ and $\mathrm{P}$ significantly higher if fertilized by goat manure+RP (T8) and poultry manure+RP (T9) compared to another treatments.
\end{abstract}

Keywords: Abelmoschus esculentus L, rock phosphate, manure, nutrient, production

\section{PENDAHULUAN}

Sistem integrasi tanaman-ternak (SITT) dicirikan oleh pemanfaatan hasil utama untuk pangan atau sayuran, sedangkan limbahnya masing-masing dapat digunakan sebagai pakan dan pupuk organik. Okra (Abelmoschus esculentus L) dulu dikenal dengan nama Hibiscus esculentus dan termasuk genus
Hibiscus (Tong, 2016). Tanaman tersebut telah lama di budidayakan dan dimanfaatkan sebagai sayuran maupun untuk pencegahan penyakit antara lain diabetes dan alzheimer (Ikrarwati dan Rokhmah, 2016). Tanaman okra mudah beradaptasi dengan lingkungan tumbuhnya. Bahkan dapat pula ditanam secara campuran (mixed cropping) bersama tanaman jagung, karena tingkat kompetisi paling rendah, 
dengan LER sekitar 1,78 (Ijoyah dan Dzer, 2012). Tinggi tanaman okra dapat mencapai 4 meter tanpa pemotongan atau pemangkasan. Apabila dilakukan pemangkasan cabang-cabang tanaman, akan memacu peningkatan produksi okra (Nadira dkk., 2009). Hijauan hasil pemangkasan tanaman okra bergizi tinggi, dapat dimanfaatkan sebagai pakan ternak kambing maupun sapi (Tong 2016), terutama dimusim kemarau atau pada saat kesulitan penyediaan pakan hijauan.

Okra dikenal dengan beberapa nama antara lain lady's finger, qin kui, okura, okro, quiabos, ochro, quiabro, bamya, bamia, bendi, bhindi, kacang bendi dan kopi arab (Jain, 2012). Tanaman okra dapat tumbuh pada dataran rendah sampai dengan dataran tinggi sekitar $1800 \mathrm{~m}$ diatas permukaan laut, dan salah satu unsur hara utama yang diperlukan yaitu $60 \mathrm{~kg} \mathrm{P} / \mathrm{ha}\left(137,4 \mathrm{~kg} \mathrm{P}_{2} \mathrm{O}_{5} / \mathrm{ha}\right.$ )(Khan dkk., 2013). Pemupukan superfosfat (TSP, SP-36) perlu dilakukan pada tanah yang defisien unsur-unsur hara tersebut, untuk meningkatkan pertumbuhan dan produksi okra. Perlu diketahui bahwa kadar unsur hara pupuk anorganik termasuk tinggi, namun selain mahal harganya juga tidak ramah lingkungan bahkan terkadang langka ketika dibutuhkan oleh petani terutama dimusim tanam. Dilain pihak, pupuk organik (kompos, pupuk kandang) termasuk ramah lingkungan tetapi nutrisinya rendah dan lambat tersedia (slow release). Oleh karena itu, pupuk organik tersebut perlu diperkaya dengan unsur hara tertentu misalnya fosfat alam (batuan fosfat) dan disebut sebagai pupuk kandang plus (pukan plus)(Lukiwati dan Pujaningsih, 2014; Lukiwati dkk., 2014).

Batuan fosfat (BP) sebagai sumber $\mathrm{P}$ alam merupakan hasil tambang, tidak larut dalam air tetapi larut dalam asam (Dierolf et al. 2001; Lukiwati dkk. 2001). Oleh karena itu, apabila batuan fosfat dicampurkan pada saat awal pembuatan pupuk kandang (pukan), maka kualitas pukan akan meningkat dan mampu meningkatkan produksi jagung setara dengan pemupukan SP-36 (Lukiwati dkk., 2010). Hal ini disebabkan karena dalam proses dekomposisi pukan, akan menghasilkan asam-asam organik (Sumida dan Yamamoto, 1997; Ye dan Yang, 1997). Rashid et al. (2004) memberikan contohnya antara lain oksalat, nitrat, sitrat, glukonat, suksinat dan asetat yang dapat meningkatkan kelarutan P-fosfat alam. Dengan demikian, pupuk kandang sebagai hasil samping penerapan SITT, dapat diperkaya nutrisinya dengan penambahan fosfat alam dan disebut dengan nama pukan plus. Penerapan pukan plus (20 t pukan/ ha $+150 \mathrm{~kg}_{2} \mathrm{O}_{5} / \mathrm{ha}$ ) telah diterapkan dalam budidaya jagung manis pada tanah vertisol (grumusol) dan ternyata masih terdapat efek residu hingga musim tanam ketiga (Lukiwati dan Pujaningsih, 2015), sehingga dapat menghemat biaya pemupukan.

Pupuk kandang mengandung unsur hara N, P dan K sekitar 0,55; 0,12 dan 0,30\% (Soelaeman, 2008). Pupuk organik merupakan sumber energi dan makanan bagi mikroba tanah (Hasanuzzaman et al., 2010), dan pupuk kandang lebih cepat ketersediaan nutrisinya untuk mikroorganisme tanah dibanding kompos (Jannoura et al. 2014). Penelitian terkini telah dilakukan dengan penerapan pupuk kandang (pukan sapi, kambing, ayam) maupun kompos azolla diperkaya fosfat alam (batuan fosfat) dalam budidaya tanaman okra, untuk diamati pengaruhnya terhadap produksi daun okra dan nutrisinya sebagai hijauan pakan ternak ruminansia.

\section{MATERI DAN METODE}

Penelitian telah dilaksanakan selama 4 bulan di kebun percobaan dengan ukuran petak masingmasing $3 \mathrm{~m}$ x $2 \mathrm{~m}$ sebanyak 27 petak. Digunakan benih okra varietas ever lucky, Azolla pinnata, pukan (sapi, kambing, ayam), pupuk batuan fosfat (BP), biodekomposer (EM-4), tetes dan peralatan kebun maupun laboratorium serta bahan kimia pendukungnya.

\section{Persiapan dan Pelaksanaan Penelitian}

Pembuatan kompos azolla dan pupuk kandang (sapi, kambing dan ayam) dilakukan terlebih dahulu, masing-masing dengan dosis $10 \mathrm{t} / \mathrm{ha}$. Demikian juga pembuatan azolla dan tiga macam pupuk kandang (sapi, kambing, ayam) diperkaya batuan fosfat masing-masing dengan dosis $60 \mathrm{~kg} \mathrm{P} / \mathrm{ha}$ ((137,4 kg $\left.\mathrm{P}_{2} \mathrm{O}_{5} / \mathrm{ha}\right)$ kemudian diperam selama satu bulan. Proses dekomposisi delapan pupuk organik tersebut dipercepat dengan penambahan tetes dan biodekomposer EM-4 (Ariyanto, 2011). Hasil analisis nutrisi delapan macam pupuk organik tersebut tercantum pada Tabel 1.

Rancangan perobaan yang digunakan adalah rancangan acak kelompok, sembilan perlakuan dan tiga kali ulangan. Perlakuan pemupukan yang diberikan adalah T1 (batuan fosfat), T2 (kompos azolla), T3 (pukan sapi), T4 (pukan kambing), T5 (pukan ayam), T6 (kompos azolla+BP), T7 (pukan sapi+BP), T8 (pukan kambing+BP), T9 (pukan ayam+BP). Persiapan 27 petak percobaan diselesaikan beberapa hari sebelum tanam, dengan ukuran masingmasing $3 \mathrm{~m} \times 2 \mathrm{~m}$. Benih okra disemaikan terlebih dahulu selama dua minggu, kemudian dipindah ke petak-petak percobaan dengan jarak tanam 50x50 $\mathrm{cm}$ sehingga masing-masing terdapat 24 tanaman. Dua hari sebelum tanam pada petak-petak percobaan tersebut telah dilakukan pemupukan organik 
Tabel 1. Nutrisi Beberapa Macam Pupuk Organik

\begin{tabular}{lcccc}
\hline \multicolumn{1}{c}{ Pupuk organik } & \multicolumn{4}{c}{ Hasil analisis } \\
\cline { 2 - 5 } & $\mathrm{N} \%$ & $\mathrm{P}_{2} \mathrm{O}_{5} \%$ & $\mathrm{~K}_{2} \mathrm{O} \%$ & $\mathrm{C} / \mathrm{N}$ \\
\hline Kompos azolla & 1,20 & 0,10 & 0,98 & 14,56 \\
Pukan sapi & 1,06 & 0,04 & 1,25 & 19,77 \\
Pukan kambing & 1,42 & 0,11 & 1,91 & 15,73 \\
Pukan ayam & 1,64 & 0,27 & 1,46 & 14,05 \\
Kompos azola+BP & 1,22 & 0,88 & 1,03 & 14,69 \\
Pukan sapi+BP & 1,09 & 0,94 & 1,32 & 18,26 \\
Pukan kambing+BP & 1,57 & 0,81 & 1,97 & 15,73 \\
Pukan ayam+BP & 1,70 & 0,99 & 1,56 & 14,43 \\
\hline
\end{tabular}

terlebih dahulu, sesuai perlakuan masing-masing. Pemangkasan tanaman okra sebagai hijauan pakan dilakukan pada umur tiga bulan setelah tanam, selanjutnya dianalisis nutrisinya.

Parameter yang diamati adalah kadar nitrogen, fosfor dan produksi hijauan okra. Semua data pengamatan tersebut kemudian dianalisis ragam dan dilanjutkan uji DMRT umtuk mengetahui perbedaan antar perlakuan.

\section{HASIL DAN PEMBAHASAN}

\section{Produksi Hijauan Okra}

Hasil analisis ragam menunjukkan bahwa perlakuan pemupukan yang diberikan berpengaruh nyata terhadap produksi hijauan okra. Data Tabel 2 menunjukkan bahwa antar perlakuan yang diberikan terdapat perbedaan nyata $(\mathrm{P}<0,05)$ terhadap produksi hijauan okra.

Tabel 2. Produksi Hijauan Okra pada Berbagai Jenis Pemupukan Organik

\begin{tabular}{lc}
\hline \multicolumn{1}{c}{ Pemupukan } & $\begin{array}{c}\text { Produksi hijauan } \\
(\mathrm{kg} / \text { petak) }\end{array}$ \\
\hline Batuan fosfat (BP) & $9,56 \mathrm{e}$ \\
Kompos azolla & $9,97 \mathrm{~d}$ \\
Pukan sapi & $9,95 \mathrm{~d}$ \\
Pukan kambing & $13,06 \mathrm{~b}$ \\
Pukan ayam & $13,10 \mathrm{~b}$ \\
Kompos azolla+BP & $10,53 \mathrm{c}$ \\
Pukan sapi+BP & $10,47 \mathrm{c}$ \\
Pukan kambing+BP & $14,58 \mathrm{a}$ \\
Pukan ayam+BP & $14,57 \mathrm{a}$ \\
*Huruf berbeda pada kolom yang sama menunjukkan berbeda nyata pada taraf \\
5\% uji DMRT
\end{tabular}

Pukan ayam maupun pukan kambing yang diperkaya BP menghasilkan produksi hijauan okra nyata lebih tinggi $(\mathrm{P}<0,05)$ dibanding perlakuan pemupukan lainnya. Meskipun ratio $\mathrm{C} / \mathrm{N}$ semua jenis pukan yang diberikan menunjukkan angka dibawah 20 yang berarti sudah memenuhi syarat untuk pemupukan (Edesi et al. 2012). Namun kadar N pada pukan ayam dan pukan kambing diperkaya BP masing-masing lebih tinggi dibanding pukan tunggal maupun pukan sapi dan kompos azolla diperkaya BP (Tabel 1). Unsur hara nitrogen berperan dalam memacu pertumbuhan vegetatif tanaman (Jannoura et al. 2014). Aplikasi pukan juga dapat meningkatkan kandungan $\mathrm{N}$ total tanah dan berperan dalam meningkatkan produksi tanaman (Mujiyati dan Supriyadi, 2009).

\section{Kadar N dan P Hijauan Okra}

Hasil analisis ragam menunjukkan bahwa perlakuan pemupukan berpengaruh nyata $(\mathrm{P}<0,05)$ terhadap kadar N dan P hijauan okra. Data Tabel 3 menunjukkan bahwa pukan ayam diperkaya BP (pukan ayam+BP) maupun yang tidak, dapat menghasilkan kadar $\mathrm{N}$ hijauan okra nyata lebih tinggi dibanding pukan sapi maupun BP. Hal ini disebabkan karena kadar $\mathrm{N}$ pukan ayam diperkaya BP maupun tidak, lebih tinggi dibanding pupuk organik lainnya (Tabel 1), sehingga meningkatkan $\mathrm{N}$ total tanah dan pada gilirannya menghasilkan kadar N hijauan okra lebih tinggi (Jannoura et al. 2013). Sebelumnya Sunarlim dkk (1999) telah menyatakan bahwa efisiensi serapan $\mathrm{N}$ pukan ayam lebih tinggi dibanding pukan sapi.

Kadar P hijauan okra dengan berbagai pupuk organik diperkaya BP, nyata lebih tinggi dibanding perlakuan pemupukan lainnya (Tabel 3). Hal ini disebabkan karena kadar P pupuk organik (azolla, pukan sapi, kambing dan ayam) diperkaya BP (pukan plus) lebih tinggi dibanding tanpa penambahan $\mathrm{BP}$ (Tabel 1).

Tabel 3. Kadar Nitrogen dan Fosfor Hijauan Okra dengan Berbagai Jenis Pemupukan Organik

\begin{tabular}{lcc}
\hline Pemupukan & Kadar nitrogen (\%) & Kadar fosfor (\%) \\
\hline Batuan fosfat (BP) & $1,11 \mathrm{c}$ & $0,25 \mathrm{e}^{*}$ \\
Kompos azolla & $2,03 \mathrm{ab}$ & $0,19 \mathrm{e}$ \\
Pukan sapi & $1,60 \mathrm{~b}$ & $0,11 \mathrm{e}$ \\
Pukan kambing & $2,13 \mathrm{ab}$ & $0,39 \mathrm{~cd}$ \\
Pukan ayam & $1,99 \mathrm{a}$ & $0,45 \mathrm{~d}$ \\
Kompos azolla+BP & $1,81 \mathrm{ab}$ & $0,59 \mathrm{bc}$ \\
Pukan sapi+BP & $1,56 \mathrm{~b}$ & $0,70 \mathrm{ab}$ \\
Pukan kambing+BP & $2,05 \mathrm{ab}$ & $0,81 \mathrm{a}$ \\
Pukan ayam+BP & $2,26 \mathrm{a}$ & $0,85 \mathrm{a}$ \\
\hline
\end{tabular}

*Huruf berbeda pada kolom yang sama menunjukkan berbeda nyata pada taraf $5 \%$ uji DMRT

Apabila pupuk BP ditambahkan pada awal pembuatan pupuk kandang (dekomposisi pukan), maka kualitas pukan akan meningkat (Lukiwati dkk., 2010). Hal ini disebabkan karena dalam proses dekomposisi pukan, akan menghasilkan asamasam organik (Rashid et al. 2004) yang mampu meningkatkan kelarutan BP sehingga dapat diabsorbsi oleh akar tanaman dan meningkatkan kadar P hijauan okra. Pupuk P organik dikombinasikan dengan pupuk kandang mampu meningkatkan serapan nutrisi, efisiensi penggunaan fosfor dan kesuburan kimia tanah (Ademba et al., 2015). 


\section{SIMPULAN}

Pukan ayam+BP dan pukan kambing+BP setara kemampuannya dalam menghasilkan produksi hijauan dan kadar nitrogen serta fosfor hijauan okra, namun lebih tinggi dibanding pemupukan organik tanpa penambahan BP.

\section{UCAPAN TERIMA KASIH}

Terima kasih kepada Imam Pranata, S.P yang telah membantu pelaksanaan penelitian dilapang dan pengolahan data.

\section{DAFTAR PUSTAKA}

Ademba, J.S., J.K. Kwach, A.O. Esilaba and S.M. Ngari. 2015. The effects of phosphate fertilizers and manure on maize yields in South Western Kenya. East African Agric. and Forestry J. 81(1): 1-11.

Ariyanto, S.E. 2011. Perbaikan kualitas pupuk kandang sapi dan aplikasinya pada tanaman jagung manis (Zea mays saccharata Sturt). J. Sain dan Teknologi. 4(2): 164-175.

Dierolf T., T. Fairhurst, and E. Mutert. 2001. Soil Fertility Kit. A toolkit for acid, upland soil fertility management in Southeast Asia. First edition. Printed by Oxford Graphic Printers. Singapore.

Edesi, L., M. Jarvan, M. Noormeths, E. Lauringson, A. Adamson, and E. akk. 2012. The importance of soil cattle manure application on soil microorganism inorganic and conventional cultivation. Acta Agric. Scandinavida. Section B-Soil \& Plant Sci. 62(7): 583-594.

Hasanuzzaman, M., K.U. Ahamed, K. Nahar, and N. Akhter. 2010. Plant growth pattern, tiller dynamics and dry matter accumulation of wetland rice (Oryza sativa L.) as influenced by application of different manures. Nature and Sciences 8:1-10.

Ijoyah, M.O., and D.M. Dzer. 2012. Yield performance of okra (Abelmoschus esculentus L. Moench) and maize (Zea mays L.) as affected by time of planting maize in Makurdi, Nigeria. ISRN Agronomy. http://dx.doi.org/10.5402/2012/485810

Ikrarwati dan N.A. Rokhmah. 2016. Budidaya Okra dan Kelor dalam Pot. Balai Pengkajian Teknologi Pertanian. Jakarta.

Jain, N. 2012. A review on Abelmoschus esculentus. Pharmacacia 1: 1-8

Jannoura, R., C. Bruns, and R.G. Joergensen. 2013. Organic fertilizer effects on pea yield, nutrient uptake, microbial root colonization, and soil microbial biomass indices in organic farming systems. European J.of Agronomy. 49: 32-41

Jannoura, R., R.G. Joergensen, and C. Bruns. 2014.
Organic fertilizer effects on growth, crop yield, and soil microbial biomass indices in sole and intercropped peas and oats under organic farming conditions. European J.of Agronomy. 52: 259-270

Khan, M. and M. Sharif. 2012. Solubility enhancement of phosphorus from rock phosphate through composting with poultry litter. Sarhad J. Agric. 28(3): 415-420.

Lukiwati, D.R., R. Ekowati dan Karno. 2001. Produksi bahan kering dan kadar protein kasar rumput setaria gajah dengan pemupukan $\mathrm{N}$ dan $\mathrm{P}$. Seminar Nasional "Pengembangan Peternakan Berbasis Sumberdaya Lokal. Fakultas Peternakan IPB, Bogor, 8-9 Agustus. Hal.167

Lukiwati, D.R. dan R.I. Pujaningsih. 2014. Efek sisa pupuk kandang diperkaya fosfat alam terhadap produksi jagung manis dan jerami di lahan kering. J. Lahan Suboptimal. 3(2): 152-160.

Lukiwati, D.R. dan R.I. Pujaningsih. 2015. Efek sisa pupuk kandang diperkaya fosfat alam dalam bentuk granular dan inokulasi biodekomposer terhadap nutrisi jerami jagung manis di lahan kering. J. Pastura. 4(2): 78-82.

Lukiwati, D.R., E.D. Purbajanti, and R.I. Pujaningsih. 2014. Sweet corn production and nutritive value of stover with manure enriched with rock phosphate fertilizer and biodecomposer. J.of Agric.Sci. and Tech. A. 4(10: 839-842

Lukiwati, D.R., Surahmanto, and B.A. Kristanto. 2010. Production and nutrient uptake improvement of sweet corn by rock phosphate combined with manure and mycorrhiza inoculation. International Conference on Balanced Nutrient Management for Tropical Agriculture. 12-16 April Kuantan, Pahang. Malaysia. Hal. 80.

Mujiyati dan Supriyadi, 2009. Pengaruh pupuk kandang dan NPK terhadap populasi bakteri Azotobacter dan Azospirillum dalam tanah pada budidaya cabai (Capsicum annum). Bioteknologi, 6(2): 63-69

Nadira, S.; B. Hatidjah dan Nuraeni. 2009. Pertumbuhan dan hasil tanaman okra (Abelmoschus esculantus) pada perlakuan pupuk dekaforan dan defoliasi. J. Agrisains, 10(1): 10-15.

Rashid, M., S. Khalil, N. Ayub, S. Alam, and F. Latif. 2004. Organic acids production and phosphate solubilization by phosphate solubilizing microorganisms (PSM) under in vitro condition. Pak. J. Biol. Sci. 7(2): 187-197.

Soelaeman, Y. 2008. Efektivitas pupuk kandang dalam meningkatkan ketersediaan fosfat, pertumbuhan dan hasil padi dan jagung pada lahan kering masam. Jurnal Tanah Trop. 13 (1): 41-47

Sumida, H., and K. Yamamoto. 1997. Effect of decomposition of city refuse compost on the 
behaviour of organic compounds in the particle size fractions. Proceeding of the XIII International Plant Nutrition Qolloquium. 13-19 September 1997, Tokyo. Japan. Kluwer Academic Publishers. London. Hal. 599-600

Sunarlim, N., W.H. Adil, F.L. Sahwan, and F. Schuchardt. 1999. The mineralization of nitrogen from two different composts in the soil. Indonesian J.of Crop Sci. 14(2): 35-40.
Tong, P.S. 2016. Okra (Abelmoschus esculentus) a popular crop and vegetable. Utar Agric. Sci. J. 2(3): 39-42.

Ye, Z. and Y. Yang. 1997. Decomposition characteristics of organic manure in soil and influence of manure application on extractable $\mathrm{Fe}$ and $\mathrm{Zn}$. Proceeding of the XIII International Plant Nutrition Qolloquium. 13-19 September 1997, Tokyo. Kluwer Academic Publishers. Hal. 597598. 